\title{
Correlation and Path Coefficient Estimation in Horsegram [Macrotyloma uniflorum(L) Verdcout] Genotypes Collected from Bastar Plateau
}

\author{
Rakesh Singh* and J. L. Salam \\ Department of Genetics and Plant Breeding, S. G. College of Agriculture and Research \\ Station, Jagdalpur-404001, Chhattisgarh, India \\ *Corresponding author
}

\section{A B S T R A C T}

Keywords

Horsegram, Macrotyloma uniflorum,

Correlation coefficient; Path coefficient

\section{Article Info}

\section{Accepted:}

15 January 2021 Available Online: 10 February 2021
Horsegram (Macrotyloma uniflorum (L) Verdcout) is a popular pulse among the tribal's of Bastar region, locally known as Hirwa or Harwa. An experiment was accompanied with 56 horsegram genotypes and 1 check Indira kulthi-1 at SGCARS Jagdalpur (C.G.), to assess correlation and path coefficient analysis for 10 quantitative characters. Result obtained from Analysis of variance revealed highly significant differences among the genotypes for all the characters under study. Correlation coefficient analysis revealed significant positive correlation for the traits plant height, primary branches and seeds per pod with seed yield per plant at both phenotypic and genotypic level. Path analysis revealed that on phenotypic class pods per plant exhibited uppermost positive direct effect trailed by primary branches, days to $50 \%$ flowering, seeds per pod, plant height and pod length whereas on genotypic class uppermost direct effect was of trait pods per plant trailed by primary branches per plant, seeds per pod, days to $50 \%$ flowering and pod length.

\section{Introduction}

Horsegram (Macrotyloma uniflorum (L) Verdcout) is an under exploited arid legume crop. Horsegram seeds are rich in protein and consumed in majority by low income section of the society. It is an important component in the dryland crop production system due to its ability to withstand drought with minimum crop management practices. It is commonly known as kulthi, hirwa or harwa in Bastarplateau region. Horsegram [Macrotyloma uniflorum (L) Verdcourt] belonging to Family: Leguminosae, Subfamily: Faboidae, Tribe: Phaseoleae, Subtribe: Phaseolinae, Genus: Macrotyloma, 
Species: uniflorum. Macrotyloma uniflorum (L) Verdcourt synonyms are Dolichosuniflorus and Dolichosbiflorus with chromosome number of $2 \mathrm{n}=2 \mathrm{x}=20,22,24$. Genus Macrotyloma consist about twenty five species; most of them are mainly present in Africa. Within Macrotyloma uniflorum (L) Verdcout four varieties have been identified viz., var. uniflorum, benadirianum, stenocarpum and verrucosum (Uma Rani et al., 2013). Horsegram is an annual succulent herb, slender, downy, slightly twining branching, springing from the base of the plant, semi-erect, low growing habit with 60 $120 \mathrm{~cm}$ height; leaves are trifoliate with 2.5 to $5.0 \mathrm{~cm}$ in length. Stipules are one $\mathrm{cm}$ long and ovate lanceolate. Peduncles are short, bisexuals, bracteate, pedicellate, zygomorphic and complete. Calyx are downy teeth lanceolate, corolla arc light yellow, 5 petals, standard petal longer than wings, stamens diadelphos $(9+1)$, filaments are alternately short and long anthers, introse, uniform diversified. Gynoecium is with superior ovary. Style file from terminal, curved, stigma capitate and hairy. Pods are linear, recurned beaked with 5-7 seeds. Seeds are normal, flattened, 3-6 mm long, black, light red, brown and mottled apperance, testa skinny with small hilum. Horsegram is a self-fertilized crop, matures in 3 to 4.5 months. The tap root produces a branched root system with smooth, rounded nodules. Nodules contain nitrogen fixing bacteria (Kumar and Vittal, 2007). During twelfth plan (2012-2015), the total area under horsegram was 2.32 lakh hectares and production was 1.05 lakh tonnes respectively. With regard of area and production, Karnataka is on the first position on all India basis sharing $26.72 \%$ and $25.71 \%$ respectively followed by Odisha sharing $19.46 \%$ area and $15.48 \%$ production and Chhattisgarh is in third position sharing $19.29 \%$ area and $13.29 \%$ production. The highest productivity was noted in the state of Bihar $(959 \mathrm{~kg} / \mathrm{ha})$ followed by W.B. (796 $\mathrm{kg} / \mathrm{ha}$ ) and Jharkhand (603 kg/ha) (Anon., 2015-16).

In Chhattisgarh during 2017-2018 area, production and productivity under crop was 47.62 ha, 16.37 MT, 344 kg/ha (Anon., 2017$18)$.

All the varieties developed to date are mainly by single plant selection from locals. There is greater need to increase the yield and quality of this crop by breeding while understanding the genetic makeup of this crop. Hence, it is essential to generate new variability through hybridization. By germplasm exploration superior germplasm's can be identified from these local varieties which can be ultimately used for developing superior lines in breeding programme. Hence looking to the above facts investigation entitled "Correlation and Path coefficient estimation in horsegram [Macrotyloma uniflorum (L) Verdcout] genotypes collected from Bastar Plateau" is being carried out with the objective " to study association of characters concerned under study with seed yield per plant".

\section{Materials and Methods}

The present experiment entitled "Correlation and Path coefficient estimation in horsegram [Macrotyloma uniflorum (L) Verdcout] genotypes collected from Bastar Plateau" was performed at Research cum Instructional Farm, Shaheed Gundadhoor College of Agriculture and Research Station, Kumhrawand, Jagdalpur, (Chhattisgarh) located at N 195'35' longitude E 81 $57^{\prime} 37^{\prime \prime}$ latitude and at an altitude ranging from 530 to 850 meters above mean sea level (MSL) with an annual rainfall $1400 \mathrm{~mm}$. The experimental material comprised of 56 horsegram genotypes along with 1 check variety i.e., Indira kulthi-1. The experimental material was planted in a Randomized Complete Block Design with three replications during kharif 
2018. Each genotype was planted in three rows of $4 \times 1 \mathrm{~m}$ plot having $30 \times 10 \mathrm{~cm}$ inter and intra row spacing. The observations were recorded on five randomly selected plants per replication for each accession.

The analysis of variance for different characters was carried out using the mean data through method given by Panse and Sukhatme (1967).

\section{Estimation of Analysis of Variance}

The analysis of variance for different characters was carried out using the mean data in order to partition the variability due to different sources by following the method given by Panse and Sukhatme (1967) (Table 1).

Where,

$\mathrm{SSB}=$ sum of square of block

$\mathrm{MSE}=$ mean sum of square of error

$\mathrm{MSB}=$ mean sum of square of block

$\mathrm{TSS}=$ total sum of square

MST $=$ mean sum of square of treatment

$\mathrm{SSE}=$ sum of square of error

$\mathrm{SST}=$ sum of square of treatment

\section{Estimation of correlation coefficient}

The correlation coefficients were worked out to determine the degree of association of a character with yield and also among the yield components. Phenotypic and genotypic correlation coefficients were computed by using the formula given by Weber and Morthy (1952). $(\boldsymbol{r p})=\frac{\operatorname{Cov}(\mathrm{xy}) \mathrm{p} \times 100}{\sigma \mathrm{p}_{\mathrm{x}} \times \sigma \mathrm{p}_{Y}}$

$(r g)=\frac{\operatorname{Cov}(\mathbf{x y}) \mathrm{g} \times 100}{\sigma \mathrm{g}_{\mathrm{x}} \times \sigma_{\mathrm{g}_{Y}}}$

Where,

$(\mathrm{rp})=$ Phenotypic correlation coefficient

$(\mathrm{rg})=$ Genotypic correlation coefficient

Cov $(x y) p=$ Phenotypic covariance between the characters ' $x$ ' and ' $y$ '

Cov (xy)g = Genotypic covariance between the characters ' $x$ ' and ' $y$ '

$\sigma \mathrm{p}_{\mathrm{X}}$ and $\sigma \mathrm{p}_{Y}=$ Phenotypic variance of the character ' $\mathrm{x}$ ' and ' $\mathrm{y}$ ' respectively

$\sigma \mathrm{g}_{\mathrm{X}}$ and $\sigma_{\mathrm{g}}=$ Genotypic variance of the character ' $\mathrm{x}$ ' and ' $\mathrm{y}$ ' respectively

Correlation coefficients were compared against ' $r$ ' values as given in Fisher and Yates (1963) table at (n-2) degrees of freedom at the probability levels of 0.05 and 0.01 to test their significance.

\section{Estimation of path coefficient}

The path analysis was originally developed by Wright (1921) and elaborated by Dewey and Lu (1959). Path coefficient analysis splits the correlation coefficients into the measures of direct and indirect effects of independent variables on dependent variable. If a character $\mathrm{y}$ is determined by correlated characters $\mathrm{x} 1, \mathrm{x} 2$ and $\mathrm{x} 3$, a path diagram must be formulated. Thus we get a set of simultaneous equations as given below:

$r(x 1, y)=a+r(x 1, x 2) b+r(x 1, x 3) c$.

$$
r(x 2, y)=b+r(x 2, x 1) a+r(x 2, x 3) c .
$$


$r(x 3, y)=c+r(x 3, x 1) a+r(x 3, x 2) b$

Considering the three factors i.e. $\mathrm{x} 1, \mathrm{x} 2$ and $\mathrm{x} 3$, the simultaneous equations given above can be matrix notation as:

$\mathrm{rx} 1 \mathrm{y}=\mathrm{rx} 1 \mathrm{x} 1 \mathrm{rx} 1 \mathrm{x} 1 \mathrm{r} \times 1 \mathrm{x} 1 \mathrm{a}$

$\mathrm{rx} 2 \mathrm{y}=\mathrm{r} \times 2 \mathrm{x} 1 \mathrm{r} \times 2 \mathrm{x} 2 \mathrm{r} \times 2 \mathrm{x} 3 \mathrm{~b}$

$r \times 3 y=r \times 3 x 1 r \times 3 \times 2 r \times 3 \times 3 c$

Where,

rx1y = Correlation coefficient between character $\mathrm{x} 1$ and $\mathrm{y}$.

rx $2 \mathrm{y}=$ Correlation coefficient between character $\mathrm{x} 2$ and $\mathrm{y}$.

rx3y = Correlation coefficient between character $\mathrm{x} 3$ and $\mathrm{y}$.

$\mathrm{a}=$ Direct effect of character $\mathrm{x} 1$ and $\mathrm{y}$.

$\mathrm{b}=$ Direct effect of character $\mathrm{x} 2$ and $\mathrm{y}$.

$c=$ Direct effect of character $\mathrm{x} 3$ and $\mathrm{y}$.

The solution for vector $\mathrm{C}$ may be obtained as follows:

$\mathrm{A}=\mathrm{B} \cdot \mathrm{C}$ or

$\mathrm{C}=\mathrm{B}-1 \mathrm{~A}$

Where,

B-1 = inverse of matrix $\mathrm{B}$.

After calculating the values of path coefficient i.e. "C" vectors the residual effect can be estimated by the given formula:

$\mathbf{R}=\mathbf{1}-\Sigma(\mathbf{r i j})$

Where,

$\mathrm{R}=$ Residual effect rij $=$ Correlation coefficient between $i^{\text {th }}$ character and $\mathrm{j}^{\text {th }}$ dependent variable

The results of path coefficient analysis are interpreted as per the following scale suggested by Lenka and Mishra (1973) (Table 2).

\section{Results and Discussion}

\section{Analysis of variance}

Analysis of variance was worked out on ten polygenic characters including yield and yield attributing traits of fifty seven genotypes.

From the analysis of variance it was observed that mean sum of squares due to genotypes were significant for all characters at 5\% level of significance under study thus exhibiting the presence of considerable genetic variability for all the traits in the experimental material. The results found were presented in Table 3.

This finding in authorization with the finding of Chahota et al., (2005), Gupta et al., (2005), Joshi et al., (2007), Ram et al., (2003), Singhal et al., (2010), Durga (2012), Varma et al., (2013), Gomashe et al., (2018) and Priyanka et al., (2019) except for petiole length.

\section{Correlation coefficient analysis}

The statistics that measures the index of relationship between two or more variables is known as correlation coefficient. It computes the mutual association between various plant character pairs and defines the component characters on which selection can be depend on for improvement in seed yield.

Through correlation coefficient analysis emphasis can be given for selecting character which is genetically correlated with the dependent character. To know the nature and magnitude of relationship existing between the traits under study correlation coefficient was 
carried out at phenotypic as well as genotypic levels. Result regarding correlation among various traits had been depicted in table 4 .

\section{Seed yield per plant (g)}

At phenotypic level seed yield per plant exhibited significant positive correlation with pods per plant (0.980), seeds per pod (0.550), primary branches per plant (0.528) and plant height (0.372).

At genotypic level primary branches per plant (0.775), seeds per pod (0.718) and plant height (0.411) were positively correlated with seed yield per plant.

\section{Days to $50 \%$ flowering}

Days to maturity was the only character which showed positive and significant association both at phenotypic (0.689) as well as at genotypic (0.740) level whereas primary branches per plant $(-0.266)$ and seeds per pod (0.423) showed significant correlation only at genotypic level with days to 50 per cent flowering.

\section{Days to maturity}

Days to maturity showed negative significant correlation with seeds per pod (-0.333), pod length $(-0.283)$ and petiole length $(-0.271)$ at genotypic level.

\section{Plant height (cm)}

Plant height was significantly positively correlated with seed yield per plant (0.372) and pods per plant (0.358) at phenotypic level.

However, at genotypic level petiole length (0.427) showed highest association value wit plant height followed by seed yield per plant (0.411), pods per plant (0.393), seeds per pod (0.301) and primary branches per plant $(0.266)$ respectively.

\section{Number of primary branches per plant}

Characters seed yield per plant (0.775) showed highest significant positive correlation with primary branches per plant trailed by pods per plant (0.668) and test weight (0.422) at genotypic level.

At phenotypic level seed yield per plant (0.528) and pods per plant (0.468) showed association with the character.

\section{Number of pods per plant}

Trait pods per plant showed positive and significant association with seeds per pod at phenotypic (0.548) and also at genotypic (0.668) level while seed yield per plant (0.980) showed association at phenotypic level only.

\section{Petiole length $(\mathrm{cm})$}

Petiole length showed positive significant correlation with plant height (0.427) and seeds per pod (0.260) at genotypic level whereas negative significant correlation with days to maturity $(-0.271)$ respectively.

\section{Pod length $(\mathrm{cm})$}

Pod length showed negative significant correlation with days to maturity $(-0.283)$ at genotypic level indicating early maturity leads to decrease in pod length.

\section{Number of seeds per pod}

Trait seeds per pod found to be positive significantly associated with seed yield per plant (0.718), days to $50 \%$ flowering (0.423), plant height $(0.301)$, pods per plant $(0.668)$ and petiole length (0.260) while negative correlated with days to maturity $(-0.333)$ at genotypic level. At phenotypic level significant positive correlated with seed yield 
per plant (0.55) and pods per plant (0.548) respectively.

\section{Test weight}

This trait at genotypic level had been found significant positively associated with primary branches per plant (0.422). However, with all other traits test weight had shown negative nonsignificant correlation.

From the above, it is clear that overall value of genotypic correlation was slightly greater than the values of phenotypic correlation, low phenotypic correlations can be explained due to masking or modifying effects of environment on genetic association between characters.

The experimental findings on correlation coefficient analysis has supported by earlier workers viz., Lad et al., (1998),Pandya et al., (2002), Roopdevi et al., (2002), Bhadait (2005), Paliwal et al., (2005), Kalia et al., (2007), Prabha et al., (2010), Neelam et al., (2014), Alle et al., (2016) and Priyanka et al., (2019).

\section{Path coefficient analysis}

Through correlation coefficient analysis we find association between various characters but it does not tell about the type of association of independent characters with the dependent character.

Path coefficient analysis splits the correlation coefficient into the measures of direct and indirect effects thus it provides information about the direct and indirect contribution of various independent characters on a dependent character.

Hence it helps in determining yield contributing and thus is useful in indirect selection. The direct and indirect effects of various traits with respect to seed yield at phenotypic level are presented in Table 5 and 6 and fig. 1.

\section{Direct effects at phenotypic and genotypic level}

Horsegram germplasm under study were exposed to path analysis to estimate the direct and indirect effect of various characters towards seed yield per plant.

Among the nine characters included in the study, six characters showed positive direct effect towards seed yield per plant in which pods per plant (0.9117) had higher positive direct effect followed by primary branches per plant (0.1070), days to 50 per cent flowering (0.0274), seeds per pod (0.0239), plant height (0.0167) and pod length (0.0025) whereas negative direct effect was shown by test weight $(-0.0428)$ followed by days to maturity $(-0.0202)$ and petiole length (-0.0078) respectively at phenotypic level.

At genotypic level highest direct effect towards seed yield per plant was shown by pods per plant $(0.6659)$ followed by primary branches per plant (0.4078), seeds per pod (0.1585), days to 50 per cent flowering (0.0919) and pod length (0.0835) whereas negative direct effect was shown by test weight (-0.1984), petiole length (-0.0401), days to maturity (-0.0132) and plant height ($0.0110)$ respectively.

The above discussed results on direct effect of characters towards seed yield per plant at genotypic level are confirmed with the findings of earlier workers viz., Yarguntappa (1987), Savithramma (1994), Nagaraja et al., (1999), Prakash and Khanure (2000), Pandya et al., (2002), Raina et al., (2002), Paliwal et al., (2005), Raina et al., (2007), Bhave et al., (2007), Khulbe et al., (2013) and Priyanka et al., (2019) 
Table.1 Skeleton of analysis of variance for seed yield and its component traits

\begin{tabular}{|c|c|c|c|c|}
\hline $\begin{array}{c}\text { Source of } \\
\text { Variation }\end{array}$ & $\begin{array}{c}\text { Degree of } \\
\text { Freedom }\end{array}$ & Sum of Square & $\begin{array}{c}\text { Mean Sum } \\
\text { of Square }\end{array}$ & F Calculated \\
\hline Replication & $(\mathrm{r}-1)$ & SSR & MSR & MSR / MSE \\
\hline Genotypes & $(\mathrm{g}-1)$ & SSG & MSG & MSG / MSE \\
\hline Error & $(\mathrm{r}-1)(\mathrm{g}-1)$ & SSE & MSE & \\
\hline Total & $\mathrm{rg}-1$ & SS total & & \\
\hline
\end{tabular}

Panse and Sukhatme (1967)

Table.2 Scale of direct and indirect effects

\begin{tabular}{|c|c|}
\hline Value of direct and indirect effects & Rate/ Scale \\
\hline $\mathbf{0 . 0 0}$ to 0.09 & Negligible \\
\hline $\mathbf{0 . 1 0}$ to 0.19 & Low \\
\hline $\mathbf{0 . 2 0}$ to 0.29 & Moderate \\
\hline $\mathbf{0 . 3 0}$ to 0.99 & High \\
\hline$>1.00$ & Very high \\
\hline
\end{tabular}

Lenka and Mishra (1973)

Fig.1 Path diagram for seed yield and its attributing traits in horse gram genotypes

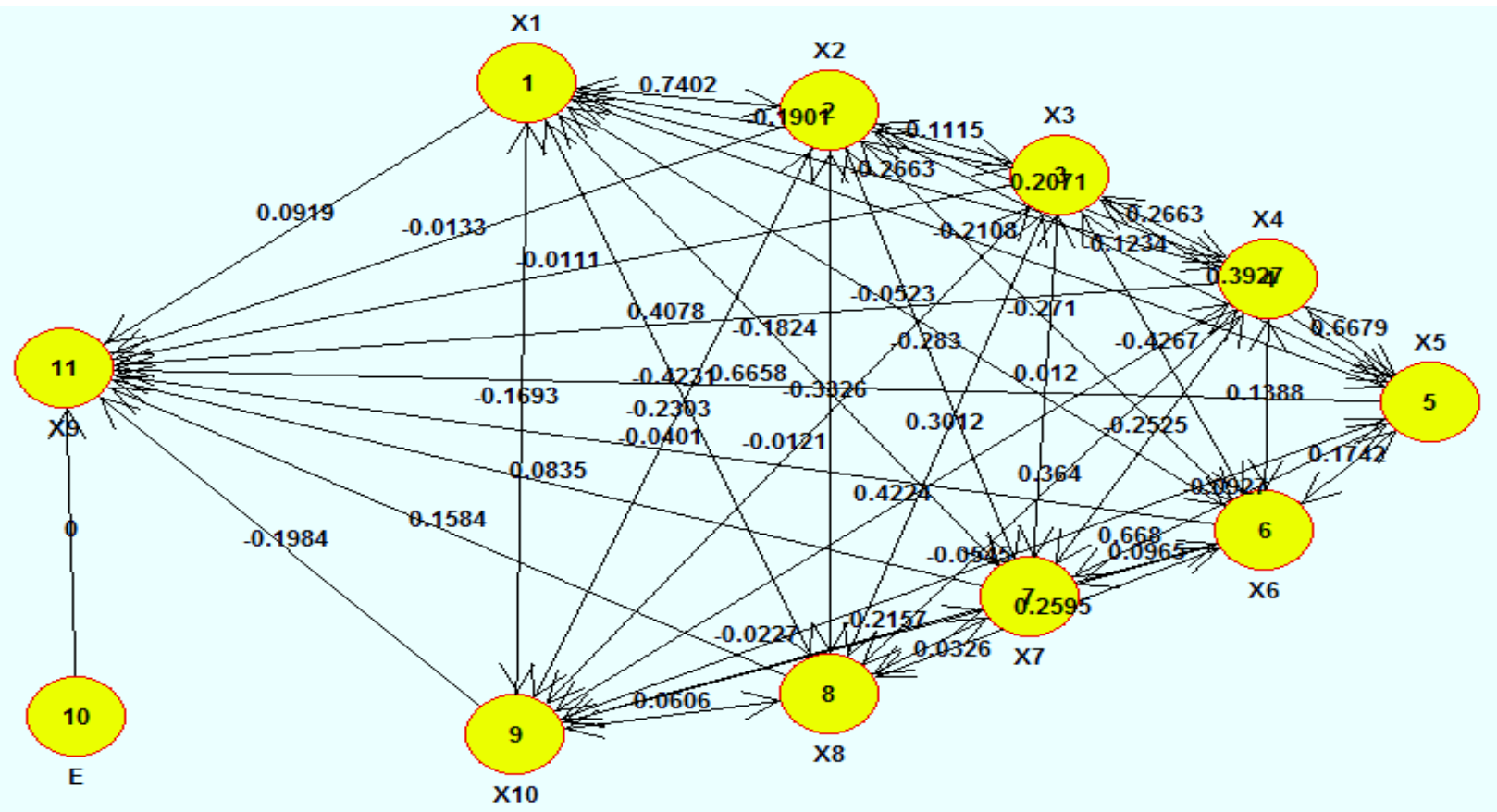


Table.3 Analysis of variance for seed yield and seed yield attributing traits in horse gram germplasm lines

\begin{tabular}{|c|c|c|c|c|c|c|c|c|c|c|c|}
\hline $\begin{array}{l}\text { Source of } \\
\text { variation }\end{array}$ & $\begin{array}{c}\text { Degree of } \\
\text { freedom }\end{array}$ & DFF & DM & $\begin{array}{c}\text { PH } \\
(\mathbf{c m})\end{array}$ & PBPP & PPP & $\begin{array}{l}\text { PeL } \\
(\mathbf{c m})\end{array}$ & $\begin{array}{c}\text { PL } \\
(\mathbf{c m})\end{array}$ & SPP & $\begin{array}{c}\text { SYPP } \\
(\mathrm{g})\end{array}$ & $\begin{array}{l}\text { TW } \\
(\mathrm{g})\end{array}$ \\
\hline Replication & 2 & 19.702 & 10.251 & 34.014 & 0.155 & 8.855 & 3.25 & 1.09 & 1.754 & 2.029 & 0.531 \\
\hline Treatment & 56 & $17.076^{*}$ & $58.539 *$ & $132.352 *$ & $1.449 *$ & $160.639 *$ & $0.714^{*}$ & $0.892 *$ & $1.231 *$ & $18.327 *$ & $6.412 *$ \\
\hline Error & 112 & 2.404 & 2.388 & 16.605 & 0.720 & 2.988 & 0.401 & 0.295 & 0.433 & 1.023 & 0.649 \\
\hline S.Em. \pm & - & 0.895 & 0.892 & 0.895 & 0.490 & 0.998 & 0.366 & 0.314 & 0.380 & 0.584 & 0.465 \\
\hline CV (\%) & - & 3.369 & 1.770 & 3.369 & 12.886 & 3.652 & 14.739 & 12.370 & 15.123 & 11.375 & 3.086 \\
\hline CD $(5 \%)$ & - & 2.512 & 2.504 & 2.512 & 1.375 & 2.800 & 1.026 & 0.880 & 1.066 & 1.639 & 1.305 \\
\hline
\end{tabular}

*Significant at $5 \%$ level of significance

$\mathrm{DFF}=$ Days to 50 percent flowering, $\mathrm{DM}=$ Days to maturity, $\mathrm{PH}=\mathrm{Plant}$ height, $\mathrm{PBPP}=\mathrm{Number}$ of primary branches per plant, $\mathrm{PPP}=\mathrm{Number}$ of pods per plant, $\mathrm{PeL}=\mathrm{Petiole}$ length, $\mathrm{PL}=$ Pod length, $\mathrm{SPP}=$ Number of seeds per pod, $\mathrm{SYPP}=$ Seed yield per plant, TW= Test weight. 
Table.4 Phenotypic and genotypic correlation coefficient analysis for seed yield and its component traits in horse gram

\begin{tabular}{|c|c|c|c|c|c|c|c|c|c|c|c|}
\hline Characters & & DFF & DM & PH & PBPP & PPP & PeL & PL & SPP & TW & SYPP \\
\hline \multirow[t]{2}{*}{ DFF } & $\mathrm{P}$ & 1 & $0.689 * *$ & -0.219 & -0.186 & -0.193 & -0.114 & -0.186 & -0.316 & -0.136 & -0.187 \\
\hline & $\mathrm{G}$ & 1 & $0.740 * *$ & -0.190 & $-0.266^{*}$ & -0.211 & -0.052 & -0.182 & $0.423 * *$ & -0.169 & -0.211 \\
\hline \multirow[t]{2}{*}{ DM } & $\mathrm{P}$ & & 1 & -0.109 & -0.141 & -0.115 & -0.183 & -0.24 & -0.245 & -0.208 & -0.119 \\
\hline & $\mathrm{G}$ & & 1 & -0.112 & -0.207 & -0.123 & $-0.271 *$ & $-0.283^{*}$ & $-0.333^{*}$ & -0.230 & -0.130 \\
\hline \multirow[t]{2}{*}{ PH } & $\mathrm{P}$ & & & 1 & 0.230 & $0.358 * *$ & -0.207 & 0.043 & 0.22 & -0.016 & $0.372 * *$ \\
\hline & $\mathrm{G}$ & & & 1 & $0.266^{*}$ & $0.393 * *$ & $0.427 * *$ & 0.012 & $0.301 *$ & -0.012 & $0.411 * *$ \\
\hline \multirow[t]{2}{*}{ PBPP } & $\mathrm{P}$ & & & & 1 & $0.468 * *$ & 0.197 & -0.081 & 0.234 & 0.266 & $0.528 * *$ \\
\hline & $\mathrm{G}$ & & & & 1 & $0.668 * *$ & 0.139 & -0.253 & 0.364 & $0.422 * *$ & $0.775 * *$ \\
\hline \multirow[t]{2}{*}{ PPP } & $\mathrm{P}$ & & & & & 1 & 0.097 & -0.078 & $0.548 * *$ & -0.058 & $0.980 * *$ \\
\hline & G & & & & & 1 & 0.174 & -0.093 & $0.668 * *$ & -0.055 & 1.018 \\
\hline \multirow[t]{2}{*}{ PeL } & $\mathrm{P}$ & & & & & & 1 & 0.115 & 0.167 & -0.133 & 0.109 \\
\hline & $\mathrm{G}$ & & & & & & 1 & 0.097 & $0.260 *$ & -0.216 & 0.228 \\
\hline \multirow[t]{2}{*}{ PL } & $\mathrm{P}$ & & & & & & & 1 & -0.019 & -0.011 & -0.774 \\
\hline & $\mathrm{G}$ & & & & & & & 1 & 0.033 & -0.023 & -0.088 \\
\hline \multirow[t]{2}{*}{ SPP } & $\mathrm{P}$ & & & & & & & & 1 & -0.068 & $0.550 * *$ \\
\hline & $\mathrm{G}$ & & & & & & & & 1 & -0.078 & $0.718 * *$ \\
\hline \multirow[t]{2}{*}{ TW } & $\mathrm{P}$ & & & & & & & & & 1 & -0.600 \\
\hline & $\mathrm{G}$ & & & & & & & & & 1 & -0.061 \\
\hline \multirow[t]{2}{*}{ SYPP } & $\mathrm{P}$ & & & & & & & & & & 1 \\
\hline & $\mathrm{G}$ & & & & & & & & & & 1 \\
\hline
\end{tabular}

** Significant at $1 \%$ level of significance

* Significant at $5 \%$ level of significance

$\mathrm{DFF}=$ Days to $50 \%$ flowering, $\mathrm{DM}=$ Days to maturity, $\mathrm{PH}=\mathrm{Plant}$ height, $\mathrm{PBPP}=$ Primary branches per plant, $\mathrm{PPP}=\mathrm{Pods}$ per plant, $\mathrm{PeL}=\mathrm{Petiole}$ length, $\mathrm{PL}=\mathrm{Pod}$ length,

$\mathrm{SPP}=$ Seeds per pod, $\mathrm{SYPP}=$ Seed yield per plant, $\mathrm{TW}=$ Test weight. 
Table.5 Phenotypic path coefficient analysis (direct and indirect) for seed yield per plant and its component traits in horse gram

\begin{tabular}{|c|c|c|c|c|c|c|c|c|c|c|c|}
\hline Characters & DFF & DM & PH & PBPP & PPP & PeL & PL & SPP & TW & SYPP \\
\hline DFF & $\mathbf{0 . 0 2 7 4}$ & -0.0139 & -0.0036 & -0.0199 & -0.1758 & 0.0009 & -0.0005 & -0.0076 & 0.0058 & -0.187 \\
\hline DM & 0.0189 & $\mathbf{- 0 . 0 2 0 2}$ & -0.0018 & -0.0151 & -0.1046 & 0.0014 & -0.0007 & -0.0059 & 0.0089 & -0.119 \\
\hline PH & -0.0060 & 0.0022 & $\mathbf{0 . 0 1 6 7}$ & 0.0246 & 0.3268 & 0.0016 & 0.0001 & 0.0052 & 0.0007 & $0.372 * *$ \\
\hline PBPP & -0.0051 & 0.0029 & 0.0038 & $\mathbf{0 . 1 0 7 0}$ & 0.4267 & -0.0015 & -0.0002 & 0.0056 & -0.0114 & $0.528 * *$ \\
\hline PPP & -0.0053 & 0.0023 & 0.0060 & 0.0501 & $\mathbf{0 . 9 1 1 7}$ & -0.0008 & -0.0002 & 0.0131 & 0.0025 & $0.980 * *$ \\
\hline PeL & -0.0031 & 0.0037 & -0.0035 & 0.0211 & 0.0887 & $\mathbf{- 0 . 0 0 7 8}$ & 0.0003 & 0.0040 & 0.0057 & 0.109 \\
\hline PL & -0.0051 & 0.0049 & 0.0007 & -0.0086 & -0.0712 & -0.0009 & $\mathbf{0 . 0 0 2 5}$ & -0.0005 & 0.0005 & -0.774 \\
\hline SPP & -0.0087 & 0.0050 & 0.0037 & 0.0251 & 0.4994 & -0.0013 & -0.0001 & $\mathbf{0 . 0 2 3 9}$ & 0.0026 & $0.550 * *$ \\
\hline TW & -0.0037 & 0.0042 & -0.0003 & 0.0284 & -0.0532 & 0.0010 & 0.0000 & -0.0014 & $-\mathbf{0 . 0 4 2 8}$ & -0.060 \\
\hline
\end{tabular}

** Significant at $1 \%$ level of significance

$\mathrm{DFF}=$ Days to 50 percent flowering, $\mathrm{DM}=$ Days to maturity, $\mathrm{PH}=\mathrm{Plant}$ height, $\mathrm{PBPP}=$ Number of primary branches per plant, $\mathrm{PPP}=\mathrm{Number}$ of pods per plant, $\mathrm{PeL}=\mathrm{Petiole}$ length, $\mathrm{PL}=$ Pod length, $\mathrm{SPP}=$ Number of seeds per pod, $\mathrm{SYPP}=$ Seed yield per plant, TW= Test weight

Table.6 Genotypic path coefficient analysis (direct and indirect) for seed yield per plant and its component traits in horse gram

\begin{tabular}{|c|c|c|c|c|c|c|c|c|c|c|c|c|c|c|}
\hline Characters & DFF & DM & PH & PBPP & PPP & PeL & PL & SPP & TW & SYPP \\
\hline DFF & $\mathbf{0 . 0 9 1 9}$ & -0.0098 & 0.0021 & -0.1086 & -0.1404 & 0.0021 & -0.0152 & -0.0670 & 0.0336 & -0.211 \\
\hline DM & 0.0681 & $\mathbf{- 0 . 0 1 3 2}$ & 0.0012 & -0.0845 & -0.0822 & 0.0109 & -0.0286 & -0.0527 & 0.0457 & -0.13 \\
\hline PH & -0.0175 & 0.0015 & $\mathbf{- 0 . 0 1 1 0}$ & 0.1086 & 0.2615 & 0.0171 & 0.0010 & 0.0477 & 0.0024 & $0.41 * *$ \\
\hline PBPP & -0.0245 & 0.0027 & -0.0029 & $\mathbf{0 . 4 0 7 8}$ & 0.4447 & -0.0056 & -0.0211 & 0.0577 & -0.0838 & $0.77 * *$ \\
\hline PPP & -0.0194 & 0.0016 & -0.0043 & 0.2724 & $\mathbf{0 . 6 6 5 9}$ & -0.0070 & -0.0077 & 0.1058 & 0.0108 & 1.018 \\
\hline PeL & -0.0048 & 0.0036 & 0.0047 & 0.0566 & 0.1160 & $\mathbf{- 0 . 0 4 0 1}$ & 0.0081 & 0.0411 & 0.0428 & 0.228 \\
\hline PL & -0.068 & 0.0037 & 0.0001 & -0.1030 & -0.0617 & -0.0039 & $\mathbf{0 . 0 8 3 5}$ & 0.0052 & 0.0045 & -0.088 \\
\hline SPP & -0.0389 & 0.0044 & -0.0033 & 0.1484 & 0.4448 & -0.0104 & 0.0027 & $\mathbf{0 . 1 5 8 5}$ & 0.0120 & $0.718 * *$ \\
\hline TW & -0.0156 & 0.0030 & 0.0001 & 0.1723 & -0.0363 & 0.0086 & -0.0019 & -0.0096 & $\mathbf{- 0 . 1 9 8 4}$ & -0.061 \\
\hline
\end{tabular}

** Significant at $1 \%$ level of significance

$\mathrm{DFF}=$ Days to 50 percent flowering, $\mathrm{DM}=$ Days to maturity, $\mathrm{PH}=\mathrm{Plant}$ height, $\mathrm{PBPP}=\mathrm{Number}$ of primary branches per plant, $\mathrm{PPP}=\mathrm{Number}$ of pods per plant, $\mathrm{PeL}=\mathrm{Petiole}$ length, $\mathrm{PL}=$ Pod length, $\mathrm{SPP}=$ Number of seeds per pod, $\mathrm{SYPP}=$ Seed yield per plant, $\mathrm{TW}=$ Test weight. 
Indirect effects at phenotypic and genotypic level

\section{Days to $50 \%$ flowering}

This character exhibited positive indirect effect on seed yield per plant through test weight $(0.0058)$ and petiole length (0.0009) at phenotypic level whereas at genotypic level plant height (0.0021), petiole length (0.0021) and test weight (0.0336) showed positive indirect effect, while rest traits showed negative indirect effect at both phenotypic and genotypic level.

\section{Days to maturity}

At phenotypic level days to maturity exhibited positive indirect effect through days to $50 \%$ flowering (0.0189), petiole length (0.0014) and test weight $(0.0089)$ while at genotypic level days to $50 \%$ flowering (0.0681), plant height (0.0012), petiole length (0.0109) and test weight (0.0457) had positive indirect effect while rest traits showed negative indirect effect on seed yield per plant at both phenotypic and genotypic level.

\section{Plant height (cm)}

It had shown in direct negative influence on seed yield through days to $50 \%$ flowering ($0.0060,-0.0175)$ while through rest of the characters indirect positive effect was shown at both phenotypic and genotypic level.

\section{Number of primary branches per plant}

It had shown indirect negative effect on seed yield through days to $50 \%$ flowering $(-0.0051$, - 0.024),petiole length $(-0.0015,-0.0056)$,pod length $(-0.0002,-0.0211)$ and test weight ($0.0114,-0.0838$ ) whereas characters days to maturity $(0.0029,0.0027)$, plant height (0.0038, -0.0029), pods per plant $(0.4267$, $0.4447)$ and seeds per pod $(0.0056,0.577)$ have positive indirect impact at both phenotypic and genotypic level.

\section{Number of pods per plant}

Number of pods per plant made negative indirect impact on seed yield per plant through days to $50 \%$ flowering $(-0.0053)$, petiole length $(-0.0008)$ and pod length $(-0.0002)$ while days to maturity (0.0023), plant height (0.0069), primary branches per plant (0.0501), seeds per pod (0.0131) and test weight (0.0025) made positive indirect impact at phenotypic level whereas at genotypic level it showed negative indirect impact on seed yield through days to 50\% flowering (-0.0194), plant height (-0.0043), petiole length $(-0.0070)$ and pod length (-0.0077) while positive indirect impact was shown through days to maturity (0.0016),primary branches per plant (0.2724),seeds per pod (0.1058) and test weight $(0.0108)$ respectively.

\section{Petiole length $(\mathrm{cm})$}

It had shown negative indirect effect towards seed yield through days to $50 \%$ flowering ($0.0031)$ and plant height $(-0.0035)$ whereas through rest characters, it had positive indirect effect at phenotypic level. However, at genotypic level it had negative indirect impact on seed yield through single character, days to $50 \%$ flowering (-0.0048) only whereas through rest of the characters, it had positive indirect impact.

\section{Pod length (cm)}

Pod length had negative indirect impact on seed yield through days to 50\% (-0.0051), primary branches per plant $(-0.0086)$, pods per plant $(-0.0712)$, petiole length $(-0.0009)$ and seeds per pod (-0.0005) while days to maturity (0.0049), plant height (0.0007) and test weight (0.0005) had positive indirect impact at phenotypic level. At genotypic level it had 
negative indirect impact on seed yield through days to $50 \%$ flowering (-0.0168), primary branches per plant (-0.1030),pods per plant ($0.0617)$ and petiole length (-0.0039) while positive indirect impact through days to maturity(0.0037), plant height (0.0001), seeds per pod (0.0052) and test weight (0.0045) respectively.

\section{Number of seeds per pod}

It had negative indirect impact on seed yield per plant through days to $50 \%$ flowering (0.0087),petiole length (-0.0013) and pod length $(-0.0001)$ while rest of the characters had positive indirect impact at phenotypic level; whereas it had showed negative indirect impact through days to $50 \%$ flowering (0.0389), plant height (-0.0033) and petiole length (-0.0104) while through days to maturity (0.0044), primary branches per plant $(0.1484)$, pods per plant $(0.4448)$, pod length $(0.0027)$ and test weight $(0.0120)$ had positive indirect impact on seed yield.

\section{Test weight (g)}

It had positive indirect impact on seed yield per plant through days to maturity (0.0042), primary branches per plant (0.0284) and petiole length (0.0010) at phenotypic level and through days to maturity (0.0030), plant height $(0.0001)$, primary branches per plant $(0.1723)$ and petiole length (0.0086)at genotypic level; whereas remaining characters were negative at both phenotypic and genotypic level.

\section{Residual effect}

In plant breeding, it is very difficult to have complete knowledge of all component traits of yield. The residual effect permits precise explanation about the pattern of interaction of other possible components of yield. The residual effect is estimated with the help of direct effects and simple correlation coefficients. In the present study the residual effect in germplasm lines of horsegram for direct and indirect effects were (0.179) at phenotypic level and (0.123) at genotypic level. The residual effect is low indicates that besides the characters studied, there are only some other attributes which contributes for yield.

In the present investigation, the genotypic correlation coefficients were in general, observed to be higher than that of phenotypic correlation coefficient indicating the strong inherent association for the various traits studied signifying the opportunity of effective phenotypic selection. Seed yield per plant exhibited significant positive association with plant height, primary branches per plant and seeds per pod at genotypic and phenotypic levels. Thus, it can be inferred that selection based on any one of these traits either alone or in combination, would result in identifying high yielding genotypes.

This study on path coefficient designated that pods per plant, primary branches per plant, days to $50 \%$ flowering and seeds per pod were the most central funders to seed yield per plant which could be taken into attention in future hybridization programs. Indirect contribution of plant height, primary branches per plant and seeds per pod through pods per plant of high magnitude was also observed. The results on path analysis indicated that, the number of pods per plant is most pronounced character contributing directly to seed yield and most of the other component characters associated to seed yield are contributing indirectly through this character.

Therefore, from this correlation and path coefficients studies it can be inferred that selection for high yield in horsegram could be enhanced by inclusion of pods per plant as a selection criteria along with the primary branches per plant and seeds per pod. 


\section{References}

Alle, R., Hemalatha, V., Eshwari, K.B. and Swarnalatha, V. 2016. Genetic variability, correlation and path analysis for yield and its components in Horsegram (Macrotyloma uniflorum [Lam.] Verdc.). Green Farming, 7:1-4.

Anonymous, 2015-16. Annu. Rep. 2015-16, Directorate of Pulses Development, Bhopal: 09.

Anonymous, 2017-18. WWW.agriportal.cg.nic.in.

Bhadait, A. 2005. Genetic diversity studies in horsegram. M.Sc. thesis, Mahatma Phule Krishi Vidyapeeth, Rahuri, Maharashtra.

Bhave, S.G., Joshi, S.N., Sawant, S.S., Bendale, V.W. and Desai, S.S. 2007. Analysis of genetic parameters for yield and certain yield contributing traits in horse gram. J. Maha. Agric. Uni., 32(2): 239-241.

Chahota, R.K., Sharma, T.R., Dhiman, K.C., Kishore, N. 2005. Characterization and evaluation of horsegram (Macrotyloma uniflorumRoxb.) germplasms from Himachal Pradesh. Indian J. Plant Genetic Res., 18(2): 221-223.

Durga, K.K. 2012.Variability and divergence in horse gram (Dolichosuniflorus). J. Arid Land, 4(1): 71-76.

Fisher, R. A. and Yates, F. 1963. Statistical tables for biological, agricultural and medical research. $6^{\text {st }}$ edition, Oliver and Boyd, Edinburgh, : 145-149.

Gomashe, S.S., Dikshit, N., Chand, D. and Shingane, S.N. 2018. Assessment of genetic diversity using morphoagronomical traits in horse gram. Int. J. Curr. Microbiol. App. Sci., 7(5): 20952103.

Gupta, A., Bhartiya, A., Singh, G., Mahajan, V. and Bhatt, J.C. 2010. Altitudinal diversity in horsegram (Macrotyloma uniflorum (Lam.) Verdc.) landraces collected from Himalayan hill region.
Plant Genetic Reso. Char. and Util., 8(3): 214-216.

Joshi, S.N., Bhave, S.G., Bendale, V.W., Jadhav, B.B. and Sawant, S.S. 2007. Analysis of genetic variability and correlation in horse gram [Macrotyloma uniflorum (Lam) Verdc.]. Research on Crops, 8(3): 632-635.

Kalia, R., Dogra, P. and Pandey, D.P. 2007. Correlation and path analysis for yield and its components in horse gram (Macrotyloma uniflorum (Lam.) Verdc.). Research on Crops, 8(2): 485-491.

Khulbe, R.K., Pant, D.P. and Singh, D.V. 2013. Genetic studies in horse gram from NW Himalayan regions of Uttarakhand, India. Crop Res., Hisar, 43(1/2/3): 194-196.

Kumar, D. and Vittal, K.P.R. 2007.Production technology for horse gram in India. Evergreen Printers, Jodhpur,: 01.

Lad, D.B., Chavan, S.A. and Dumbre, A. D. 1998.Genetic variability and correlation studies in horse gram. J. Maha. Agric.Uni., 23(3): 268-271.

Lenka, D. and Mishra, B. 1973.Path coefficient analysis of yield in rice varieties.Indian. J. Agric. Sci., (43): 376379.

Nagraja, N., Nehru, S.D. and Manjunath, A. 1999.Plant type for high yield in horse gram as evidence by path coefficients and selection indices. Karnataka J. Agric. Sci., 12 (1-4 combined): 32-37.

Neelam, S., Kumar, V., Natarajan, S., Venkateshwaran, K. and Pandravada, S.R. 2014. Evaluation and diversity observed in horse gram (Macrotyloma uniflorum (Lam) Verdc.) germplasm from Andra Pradesh, India. Int. J. Plant Res., 4(1): 17-22.

Paliwal, R.V., Sodani, S.N. and Jain, L.K. 2005.Correlation and path analysis in horse gram [Macrotyloma uniflorum (Lam) Verdc.]. J. Arid Leg., 2(2): 309310. 
Pandya, R., Ram, B., Vaid, B. and Sharma, L.K. 2002. Correlation and path analysis for yield in horse gram under two rainfall regimes. Advances in Arid Leg. Res., 123-125.

Panse, V.G. and Sukhatme, P.V. (1967). Statistical Methods for Agricultural Research Workers. $3^{\text {rd }}$ edition, ICAR, New Delhi.

Prakash, B.G. and Khanure, S.K. 2000. Genetic parameters, correlation and path coefficient analysis in horsegram. Karnataka J. Agric. Sci., 13(2): 313-314. Priyanka, S., Sudhagar, R., Vanniarajan, C. and Ganesamurthy, K. 2019. Investigation on genetic variability parameters and association of traits in horsegram (Macrotyloma uniflorum (Lam) Verdc.). Int. J. Curr. Microbiol. App. Sci., 8(2): 656-664.

Raina, S.K. 2002. Genetic parameters and association analysis in horsegram (Macrotyloma uniflorum (Lam.) Verde.)M.Sc, Thesis, CSK HPKV, Palampur, India.

Raina, S.K., Dogra, R.K. and Kapila, R.K. 2007. Variation and character association in horse gram (Macrotyloma uniflorum (Lam.) Verdc.) germplasm of North Western Himalayas. Crop Improvement, 34(2): 197-201.

Ram, B., Pandya, R., Sharma, L.K. and Vaid, B. 2003. Genetical study of variability parameters in horse gram. Adv. Arid Leg. Res., 120-122.

Roopadevi, V.D., Vishwanath, A.P., Shivakumar, H.K. and Devkumar, N. 2002. Correlation and regression studies in horse gram (Macrotyloma uniflorum Lam. Verde.). Mysore J. Agric. Sci., 36(3): 208-211.

Savithramma, D.L. 1994. Genetic divergence studies in horse gram [Macrotyloma uniflorum L.Verdec]: An approach to identify morphological and physiological traits for higher production. Ph.D. Thesis, U.A.S., Bangalore.

Singhal, H.C., Tomar, S.S., Baraiya, B.R., Sikarwar, R.S. and Tomar, I.S. 2010. Study of genetic divergence in horse gram (Macrotyloma uniflorumL.). Leg. Res., 33(2): 119-123.

Uma Rani, K., Narayanaswamy, S., Nethra, N., and Rajendra Prasad, S. 2013. Utilization of SSR markers for identification of horse gram [Macrotyloma uniflorum (Lam.)] genotypes. Annals of Plant Sci., 02 (12): 556-562.

Varma, V.S., Durga, K.K. and Ankaiah, R. 2013. Assessment of genetic diversity in Horse gram (Dolichos uniflorus).Elec. J. Plant Breeding, 4(2), 1175-1179.

Weber, C.R. and Morthy, B. R. 1952. Heritable and non-heritable relationship and variability of oil content and agronomic characteristics in the $\mathrm{F}_{2}$ generation of soybean crosses. Agro. J., 44: 202-209.

Yarguntappa, R. 1987. Studies on genetic variability, correlation and path coefficient analysis in horse gram [Macrotyloma uniflorum L. Verdec]. M.Sc. Thesis, U.A.S., Bangalore.

\section{How to cite this article:}

Rakesh Singh and Salam, J. L. 2021. Correlation and Path Coefficient Estimation in Horsegram [Macrotyloma uniflorum (L) Verdcout] Genotypes Collected from Bastar Plateau. Int.J.Curr.Microbiol.App.Sci. 10(02): 1647-1660. doi: https://doi.org/10.20546/ijcmas.2021.1002.195 